\title{
Effects of Whole Cottonseed Diet and Recombinant Bovine Somatotropin on Ovarian Follicles in Lactating Dairy Cows ${ }^{1}$
}

\author{
T. Kassa, ${ }^{\star, 2}$ J. D. Ambrose, ${ }^{*, 3}$ A. L. Adams, ${ }^{*, 4}$ C. Risco,† C. R. Staples, ${ }^{*}$ \\ M.-J. Thatcher, $\dagger$ H. H. Van Horn, ${ }^{*}$ A. Garcia, ${ }^{\star}$ H. H. Head, ${ }^{*}$ and W. W. Thatcher* \\ *Department of Animal Sciences, \\ Institute for Food and Agricultural Sciences and \\ †College of Veterinary Medicine, \\ University of Florida, Gainesville 32611
}

\section{ABSTRACT}

The effects of whole cottonseed (WCS) in the diet and the administration of bovine somatotropin (bST) on ovarian follicular dynamics and plasma progesterone $\left(\mathrm{P}_{4}\right)$ concentrations were examined in cows during a period of synchronized follicular growth. Lactating Holstein cows $(n=28)$ were randomly assigned to treatments in a $2 \times 2$ factorial arrangement. Diets consisted of WCS (15\% of dry matter) or no WCS, and bST at a dose of 0 or $208 \mathrm{mg} / 14 \mathrm{~d}$. Dietary treatments began within $24 \mathrm{~h}$ of calving and bST treatments began within $7 \mathrm{~d}$ postpartum. Cows received GnRH at $65 \pm 3 \mathrm{~d}$ postpartum (d 0), $\mathrm{PGF}_{2 \alpha}$ (d 7), a second dose of GnRH (d 9 ), and were inseminated $16 \mathrm{~h}$ later (d 10). Ovarian changes were monitored daily by ultrasonography from d 0 to 9 . On d 9, 93\% of cows had a preovulatory follicle and $86 \%$ ovulated. For Class 2 (6 to $9 \mathrm{~mm}$ ) follicles, a diet $\times$ bST interaction was detected, with bST stimulating Class 2 follicles in cows fed WCS, but not in cows on the control diet. Neither diet nor bST affected numbers of Class 1 ( 2 to $5 \mathrm{~mm}$ ) or Class $3(\geq 10 \mathrm{~mm}$ ) follicles or sizes of the subordinate and dominant follicles. During the luteal phase of the cycle, lactating cows fed WCS tended to have elevated concentrations of plasma $\mathrm{P}_{4}$, whereas bST was without effect. Plasma concentrations of high-density lipoprotein cholesterol were increased in cows fed WCS. Number and diameter of corpora lutea did not differ among treatments.

Received January 3, 2002.

Accepted June 18, 2002.

Corresponding author: W. W. Thatcher; e-mail: thatcher@ animal.ufl.edu.

${ }^{1}$ This paper is the result of independent research and does not represent the findings or views of the U.S. FDA or the United States.

${ }^{2}$ Present address: Institute of Pathobiology, Addis Ababa University, P.O. Box 1176, Ethiopia.

${ }^{3}$ Present address: Livestock Development Division, Alberta Agriculture Food and Rural Development, 6909116 St., Edmonton, Alberta, T6H 4P2 Canada.

${ }^{4}$ Present address: U.S. FDA, Center for Veterinary Medicine, 7500 Standish Place, Rockville, MD 20855.
(Key words: dairy cow, follicle, somatotropin, whole cottonseeds)

Abbreviation key: $\mathbf{C L}=$ corpus luteum, $\mathbf{H D L}=\mathrm{High}$ density lipoprotein cholesterol, $\mathbf{P}_{4}=$ progesterone, $\mathbf{W C S}$ = whole cottonseed.

\section{INTRODUCTION}

Major increases in dairy cow milk production occur with the use of recombinant bST (Bauman, 1992). However, such increases in milk yield are often associated with reduced reproductive performance (Bauman, 1992; Cole et al., 1992). Lactating cows treated with bST at 36 or $40 \mathrm{mg} / \mathrm{d}$ had an increased incidence of undetected estrus (Kirby et al., 1997b) and ovarian acyclicity (Waterman et al., 1993). Progesterone $\left(\mathbf{P}_{4}\right)$ and baseline LH concentrations in peripheral plasma decreased in cows given $\mathrm{bST}$ at $40 \mathrm{mg} / \mathrm{d}$ (Waterman et al., 1993). In contrast, progesterone concentrations and pulse frequency of LH secretion increased with bST given at a lower dose rate of $25 \mathrm{mg} / \mathrm{d}$ (Schemm et al., 1990), although baseline LH was suppressed. These effects of bST may be mediated by alterations in hypothalamic, pituitary, and/or ovarian functions. The majority of the adverse manifestations on reproduction are thought to result from the negative energy status of cows with high milk yield (Butler and Smith, 1989; Cole et al., 1991). Administration of bST at the recommended dose rate of $36 \mathrm{mg} / \mathrm{d}$ can further exacerbate the negative energy balance state of high-producing cows, making it difficult to differentiate between a direct effect of bST and the confounding effect of enhanced milk production on reproductive function. However, bST administered at a low dose rate of $5 \mathrm{mg} / \mathrm{d}$ during the early postpartum period has the potential to improve the reproductive performance of dairy cows (Stanisiewski et al., 1992) without compromising the advantage of a bST-induced increase in milk production.

Milk production in dairy cows is an energy-expensive process that demands an increased supply of nutrients and induces changes in blood levels of insulin, IGF, 
and growth hormone, which could alter reproductive functions (Bauman and Currie, 1980; Lucy et al., 1991a; Staples et al., 1990). Slower rates of follicular growth occurred in lactating cows fed a lower energy diet (Lucy et al., 1992). Dietary fat supplementation to lactating dairy cows, may, in addition to reducing potential energy deficiencies, have specific beneficial effects on reproduction (Grummer and Carroll, 1991; Sklan et al., 1991; Staples et al., 1998). In cows fed supplemental fat, there are reports of increased plasma concentrations of cholesterol and $\mathrm{P}_{4}$ (Carroll et al., 1992; Grummer and Carroll, 1991; Hightshoe et al., 1991; Williams, 1989), and an increase in size of the preovulatory follicle (Hightshoe et al., 1991; Lucy et al., 1991b, 1993b). Mechanisms by which fat supplementation may improve reproductive performance have been proposed (Grummer and Carroll, 1991; Mattos et al., 2000; Staples et al., 1998).

The objective of this experiment was to examine the effects of feeding whole cottonseed (WCS) as a dietary fat supplement and administering bST at a low dose on ovarian function of postpartum dairy cows. A specific aim was to characterize ovarian changes occurring during a period of synchronized follicular growth following the administration of $\mathrm{GnRH}$ in cows receiving either WCS or bST separately or together. It was hypothesized that by feeding a diet containing WCS, the increased availability of supplemental fat to high-producing cows will differentially affect ovarian responses to bST.

\section{MATERIALS AND METHODS}

This study was conducted at the Dairy Research Unit of the University of Florida in Hague. The experiment was part of a larger project involving 186 cows to study the effects of WCS feeding and bST on milk production, health, and reproductive performance during the postpartum period. Cows were housed in an open-sided, free-stall barn with grooved concrete floors. The diets were TMR formulated according to the requirements for lactating Holstein cows (NRC, 1988). Within $24 \mathrm{~h}$ of calving, cows received one of two experimental diets ad libitum (Table 1). All cows that were on the bST treatment received $208 \mathrm{mg}(0.5 \mathrm{ml})$ of bST (Posilac, Protiva Co., St. Louis, MO) subcutaneously at 2-wk intervals starting within $7 \mathrm{~d}$ of calving. This dose of bST is about $42 \%$ of the standard recommended commercial dose rate. Cows that calved normally, and with no apparent periparturient disorder, were assigned randomly to one of four treatments in a $2 \times 2$ factorial arrangement. Treatments consisted of a WCS diet (15\% of DM) with bST (+WCS +bST) or without bST (+WCS -bST), and a control (no WCS) diet with bST (-WCS $+\mathrm{bST})$ or without bST $(-\mathrm{WCS}-\mathrm{bST})$. All cows received
$\mathrm{PGF}_{2 \alpha}$ (25 mg intramuscularly; Lutalyse, PharmaciaUpjohn Co., Kalamazoo, MI) at $30 \pm 3$ d postpartum. Blood samples were collected three times a week from calving until initiation of the synchronization protocol.

For the present experiment, 28 cows ( $\mathrm{n}=7$ per treatment) were submitted to a timed insemination protocol (Burke et al., 1996; Pursley et al., 1995) to induce and synchronize follicular recruitment, growth, and ovulation. The preovulatory follicular wave emergence was synchronized to increase experimental sensitivity. Briefly, cows were injected with $100 \mu \mathrm{g}$ of GnRH intramuscularly (Cystorelin, Sanofi Inc., Merial Co., Athens, GA) at $65 \pm 3 \mathrm{~d}$ postpartum (Friday, $1600 \mathrm{~h}$; d 0 ) followed by $25 \mathrm{mg}$ of $\mathrm{PGF}_{2 \alpha}$ intramuscularly $7 \mathrm{~d}$ later (e.g., 72 d postpartum; Friday, 1600 h; d 7). All cows received a second injection of GnRH $2 \mathrm{~d}$ after the injection of $\mathrm{PGF}_{2 \alpha}$ (e.g., $74 \mathrm{~d}$ postpartum; Sunday $1600 \mathrm{~h}$; d 9), and were inseminated $16 \mathrm{~h}$ later (Monday, $0800 \mathrm{~h}$; d 10). The first GnRH injection induces LH and FSH secretion, which causes ovulation or luteinization of dominant follicles present in the ovaries and recruitment of a new follicular wave; the $\mathrm{PGF}_{2 \alpha}$ injection induces luteolysis, and the second injection of $\mathrm{GnRH}$ induces maturation and ovulation of the preovulatory follicle. Accordingly, this protocol sequentially synchronizes follicular development, regression of the corpus luteum (CL), and ovulation (Pursley et al., 1995).

Experimental data collection by daily ultrasonography started on the day of the first GnRH (d 0), 6 to 8 $\mathrm{h}$ preceding injection, and continued until the day of the second GnRH injection (d 9). All cows were scanned again the day after the timed insemination (d 11) to confirm ovulation of the previously identified dominant follicle. Cows that had not ovulated by d 11 were examined by ultrasonography for two additional days. If ovulation did not occur by d 13, the cows were considered anovulatory.

Blood samples were collected daily from a coccygeal blood vessel into sterile vacutainer tubes containing EDTA (Becton Dickinson, East Rutherford, NJ), placed in ice immediately upon collection, and centrifuged $\left(3000 \times g\right.$ for $20 \mathrm{~min}$ at $\left.4^{\circ} \mathrm{C}\right)$ within $6 \mathrm{~h}$. The harvested plasma was stored at $-20^{\circ} \mathrm{C}$ until analyzed for plasma $\mathrm{P}_{4}$ by radioimmunoassay (Knickerbocker et al., 1986). The intra- and interassay coefficients of variation were 6.6 and $6.7 \%$, respectively.

A real-time ultrasound unit (Aloka SSD-500, Aloka Co., Ltd., Tokyo, Japan) equipped with a 7.5-MHz linear-array transrectal transducer was used to monitor ovarian structures. At each scanning, the position and size of follicles $(\geq 2 \mathrm{~mm})$ and CL in the ovaries relative to other ovarian structures were recorded on ovarian maps. Follicular responses examined were: number of small (Class 1;2 to $5 \mathrm{~mm}$ ), medium (Class 2; 6 to 9 
Table 1. Ingredients and chemical composition of experimental diets.

\begin{tabular}{|c|c|c|}
\hline Item & $\begin{array}{l}\text { Diet with } \\
\text { whole cottonseed }\end{array}$ & $\begin{array}{l}\text { Diet without } \\
\text { whole cottonseed }\end{array}$ \\
\hline & 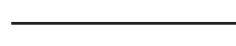 & 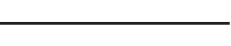 \\
\hline \multicolumn{3}{|l|}{ Ingredients } \\
\hline Corn silage & 21.70 & 22.37 \\
\hline Alfalfa hay & 9.13 & 11.69 \\
\hline Cottonseed hulls & 5.57 & 5.57 \\
\hline Citrus pulp & 10.06 & 9.94 \\
\hline Hominy & 15.36 & 20.31 \\
\hline Distillers grains & 9.19 & 13.40 \\
\hline Soybean meal & 8.80 & 11.38 \\
\hline Whole cottonseed & 14.95 & 0.00 \\
\hline Mineral mix ${ }^{1}$ & 5.34 & 5.34 \\
\hline \multicolumn{3}{|l|}{ Chemical composition } \\
\hline $\mathrm{CP}$ & 18.06 & 18.05 \\
\hline Undegradable intake protein & 6.19 & 6.58 \\
\hline $\mathrm{NE}_{\mathrm{L}}, \mathrm{Mcal} / \mathrm{kg}$ & 1.71 & 1.65 \\
\hline $\mathrm{ADF}$ & 24.21 & 20.84 \\
\hline Fat & 6.04 & 3.56 \\
\hline $\mathrm{Ca}$ & 1.10 & 1.09 \\
\hline $\mathrm{P}$ & 0.57 & 0.57 \\
\hline $\mathrm{Mg}$ & 0.35 & 0.33 \\
\hline $\mathrm{K}$ & 1.44 & 1.49 \\
\hline $\mathrm{S}$ & 0.25 & 0.25 \\
\hline
\end{tabular}

${ }^{1}$ Contained $12.0 \% \mathrm{Ca}, 2.8 \% \mathrm{P}, 2.9 \% \mathrm{Mg}, 1.0 \% \mathrm{~S}, 1.6 \% \mathrm{~K}, 7.8 \% \mathrm{Na}, 800 \mathrm{ppm}$ of $\mathrm{Zn}, 320 \mathrm{ppm}$ of $\mathrm{Cu}, 800$ $\mathrm{ppm}$ of Fe, $800 \mathrm{ppm}$ of Mn, 242,000 IU/kg of vitamin A, 35,200 IU/kg of vitamin D, and $880 \mathrm{IU} / \mathrm{kg}$ of vitamin E.

$\mathrm{mm}$ ), and large (Class $3 ; \geq 10 \mathrm{~mm}$ ) follicles, diameters of the dominant (largest) follicle, subordinate (second largest) follicle, and the CL.

Blood samples, collected 1, 2, 6, 7, 10, and $11 \mathrm{wk}$ postpartum from 60 of the 186 cows included in the larger project, were analyzed for plasma high-density lipoprotein cholesterol (HDL) by Sigma Procedure No. 352 (Sigma Chemical Co., St. Louis, MO) with certain modifications (Adams, 1998).

\section{Statistical Analysis}

Data were analyzed using the repeated measures analysis of the Mixed Procedure (Littell et al., 1996) of SAS (SAS Inst., Inc., Cary, NC) and a first-order autoregressive structure to adjust for autocorrelation between sequential measurements. Plasma concentrations of $\mathrm{P}_{4}$, total numbers of Class 1, 2, and 3 follicles, number and size of CL, and the size of dominant and subordinate follicles on the ovary were analyzed as dependent variables. The mathematical model included effects of treatment (diet, bST), ovulation (whether cows ovulated or not to the first injection of $\mathrm{GnRH}$ ), treatment $\times$ ovulation, experimental day, all higher-order interactions, and CL number as a covariate. Cow within treatment $\times$ ovulation was a random effect. Orthogonal contrasts for treatment effects were: WCS vs no WCS, bST vs no bST, and interaction of WCS and bST. The follicular Class 2 responses also were analyzed by test- ing homogeneity of regression curves for day trends among treatments as described by Wilcox et al. (1990). Briefly, a single polynomial regression for day was fitted to an individual dependent variable (single pooled curve), and the differences from fitting individual regressions for effects of WCS, bST, and WCS $\times$ bST interaction curves were tested. Differences were declared significant at $P<0.05$.

Results pertaining to HDL also were analyzed using the Mixed Procedure of SAS (SAS Inst., Inc.), with the model including effects of treatment, week, and treatment $\times$ week. A first-order autoregressive structure was used to adjust for autocorrelation between sequential measurements. Random effects were cow within treatment, batch, batch $\times$ cow within treatment, batch $\times$ week, week $\times$ cow within treatment, and batch $\times$ treatment $\times$ week. Batch represents the series of samples analyzed as a group with its respective enzyme calibrator standard.

\section{RESULTS}

\section{Ovulation Response}

On $\mathrm{d} 0$ of the experiment, 22 of $28(78.6 \%)$ cows had at least one CL, and nine cows $(32.1 \%)$ had multiple CL. Occurrences of one or multiple CL at $d 0$ were distributed evenly among the treatment groups. On $d$ $0,89 \%$ (25/28) of the cows had Class 3 follicles $(\geq 10$ 
$\mathrm{mm}$ ). In response to the first GnRH injection, 50\% (14/ 28 ) of the cows ovulated, and the ovulatory response was distributed evenly among the treatment groups. More than one CL was detected in 4, 3, 3, and 4 cows in treatments -WCS -BST; -WCS + BST; +WCS -BST; and + WCS + BST, respectively, between $\mathrm{d} 3$ and 7 . On d 9, 93\% (26/28) of the cows had a dominant (preovulatory) follicle and $86 \%(24 / 28)$ ovulated in response to the second injection of $\mathrm{GnRH}$. Of the four cows that did not ovulate in response to second $\mathrm{GnRH}$, two (7\%) underwent premature CL regression before injection of $\mathrm{PGF}_{2 \alpha}$ and ovulated spontaneously before the second GnRH injection, whereas the remaining two cows (7\%) failed to ovulate even though a potential ovulatory follicle was present at the time of second GnRH injection.

Two other cows (7\%) were determined to be anestrus based on retrospective analysis of plasma $\mathrm{P}_{4}$ concentrations from day of calving to initiation of $\mathrm{GnRH}$ treatment. Despite being anestrous, both cows responded to GnRH treatment, developed a dominant follicle, and ovulated following the second GnRH injection. Each of these cows also ovulated a follicle in response to the first GnRH injection, but did not form a fully functional CL, as plasma $\mathrm{P}_{4}$ concentrations were low and never exceeded $2.5 \mathrm{ng} / \mathrm{ml}$. Of the 28 cows, five had plasma $\mathrm{P}_{4}$ concentrations $>1.0 \mathrm{ng} / \mathrm{ml}$ on d 10 (i.e., at the time of insemination). Three of these five cows had $\mathrm{P}_{4}$ concentrations $>1.0 \mathrm{ng} / \mathrm{ml}$ on $\mathrm{d} 7$ (at the time of $\mathrm{PGF}_{2 \alpha}$ injection), indicating that their CL were nonresponsive to the luteolytic dose of $\mathrm{PGF}_{2 \alpha}$.

\section{Ovarian Follicular Populations}

Significant day effects were detected for Class 1 and Class 3 follicles, and an ovulation $\times$ day interaction was detected for Class 3 follicles; however, neither the WCS diet nor the addition of bST altered the number of Class 1 and 3 follicles during the experimental period (Figure 1 ). In cows that ovulated in response to $\mathrm{GnRH}$, there was a decrease in number of Class 3 follicles followed by an increase until $\mathrm{d} 9$ at the time of the second $\mathrm{GnRH}$ injection. The mean number of Class 2 follicles was influenced significantly $(P<0.005)$ by a treatment $x$ day interaction $(P<0.05)$. Further examination of the differences among the day trends for treatments detected a WCS $\times$ bST interaction $(P<0.01)$, which is depicted in Figure 2. In the absence of WCS, the increase in Class 2 follicles occurred on d 2, with a rapid sustained decrease observed in bST-treated cows. In the presence of WCS, the increase in Class 2 follicles was delayed until $\mathrm{d} 3$, and was markedly stimulated in cows treated with bST. In other words, injection of bST in the presence of an additional supply of fat via WCS caused a sustained increase in the number of
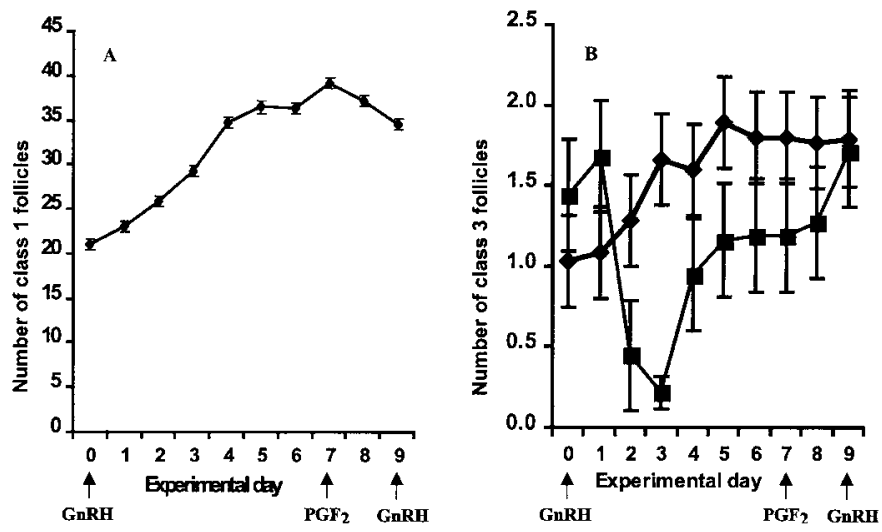

Figure 1. Least-squares means for (A) number of Class 1 follicles (2 to $5 \mathrm{~mm}$ ), (B) number of Class 3 follicles $(\geq 10 \mathrm{~mm}$ ) in cows that ovulated $(\boldsymbol{\square}, \mathrm{n}=14)$ after $\mathrm{GnRH}$ was administered on $\mathrm{d} 0$, and cows that did not ovulate $(\bullet, \mathrm{n}=14)$. Cows were given $\mathrm{GnRH}$ on $\mathrm{d} 0$ and 9, and a luteolytic dose of $\mathrm{PGF}_{2 \alpha}$ on $\mathrm{d} 7$ of the experimental period.

Class 2 follicles. Although recruitment of Class 2 follicles was stimulated in response to bST in cows fed WCS, this stimulation did not increase the number of subsequent Class 3 follicles or the ovulation rate. The number of CL on the ovary did not alter the changes in Class 1, 2, and 3 follicles.

\section{Growth of Dominant and Subordinate Follicles}

A retrospective examination of the dominant follicles indicated that size did not differ among treatments but
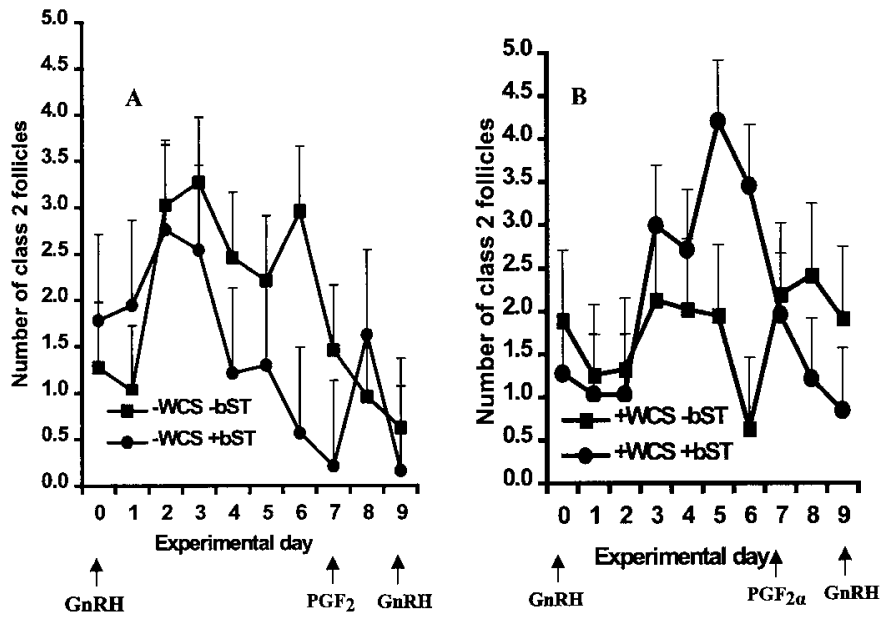

Figure 2. Least-squares means for number of Class 2 follicles (6 to $9 \mathrm{~mm} ; \mathrm{n}=7$ cows per treatment) in lactating cows fed diets that (A) did not contain whole cottonseed (-WCS) with $(+, \mathbf{\bullet})$ or without $(-$, ) bST injections, or (B) cows fed whole cottonseed (+WCS) diets with $(+, \bullet)$ or without $(-, \mathbf{\square})$ bST injections. Cows were given $\mathrm{GnRH}$ on $\mathrm{d} 0$ and 9 , and a luteolytic dose of $\mathrm{PGF}_{2 \alpha}$ on $\mathrm{d} 7$ of the experimental period. 

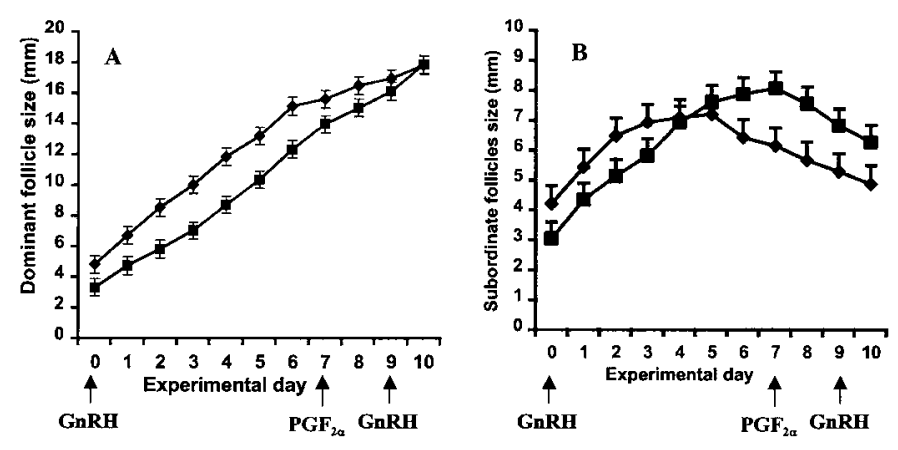

Figure 3. Least-squares means for diameter ( $\mathrm{mm}$ ) of the dominant follicle (A) and subordinate follicle (B) of cows that ovulated after administration of $\mathrm{GnRH}$ on $\mathrm{d} 0(\mathbf{\square}, \mathrm{n}=14)$ and cows that did not ovulate $(\bullet, \mathrm{n}=14)$. Cows were given $\mathrm{GnRH}$ on $\mathrm{d} 0$ and 9 , and a luteolytic dose of $\mathrm{PGF}_{2 \alpha}$ on $\mathrm{d} 7$ of the experimental period.

an ovulation $\times$ day interaction was detected $(P<0.01$; Figure 3A). Cows that ovulated in response to the first GnRH had a smaller size dominant follicle until d 9 when they received $\mathrm{GnRH}$, and their preovulatory sizes on $\mathrm{d} 10$ were the same as cows that did not ovulate after the first injection of GnRH.

Growth curves for subordinate follicles did not differ among treatments. However, an ovulation $\times$ day interaction was detected $(P<0.05$; Figure $3 \mathrm{~B})$. In cows that ovulated after the first $\mathrm{GnRH}$, the size of the subordinate follicle was smaller through $\mathrm{d} 4$, and was larger after d 6. Likewise, dominance, as measured by the day when the subordinate follicle decreased in size, occurred later (i.e., d 8 vs d 6; Figure 3B) in cows that ovulated their original dominant follicle in response to GnRH.

\section{Plasma $\mathbf{P}_{\mathbf{4}}$ Concentrations, $\mathrm{CL}$, and Pregnancy}

Sixteen cows that had a plasma $\mathrm{P}_{4}$ profile comparable to that expected during a normal diestrous phase, in which a CL was present throughout the experimental period from injection of $\mathrm{GnRH}(\mathrm{d} 0)$ to $\mathrm{PGF}_{2 \alpha}$ injection (d 7), were used in this analysis. The other 12 cows had either spontaneously regressed the CL 1 to $2 \mathrm{~d}$ before administration of $\mathrm{PGF}_{2 \alpha}$ on $\mathrm{d} 7$, or had been in estrus either at the time of the first $\mathrm{GnRH}$ injection or during the period before administration of $\mathrm{PGF}_{2 \alpha}$. Progesterone concentrations tended to be higher $(P<0.08)$ in cows fed WCS $(10.2>8.3 \mathrm{ng} / \mathrm{ml}$; pooled SE $\pm 0.71 \mathrm{ng} /$ $\mathrm{ml})$. Among the 16 cows in the luteal phase, 11 cows had more than one CL and were balanced across treatments. Mean number of CL did not differ among the four treatments $(1.55 \pm 0.08)$. Similarly, CL diameter also did not differ among treatments $(32.7 \pm 0.3 \mathrm{~mm})$, although cows receiving the WCS diet had a tendency
Table 2. Least-squares means and SE of postluteal phase plasma progesterone concentrations between $\mathrm{d} 7$ and 10 for cows fed WCS $(+/-)$ and injected with bST (+/-). Only cows in true luteal phase (n = 16) are included, and progesterone concentrations were adjusted for CL number. All cows received $\mathrm{PGF}_{2 \alpha}$ on $\mathrm{d} 7$.

\begin{tabular}{lrlll}
\hline & \multicolumn{4}{c}{ Progesterone $(\mathrm{ng} / \mathrm{ml})$} \\
\cline { 2 - 5 } Treatment $^{1}$ & \multicolumn{1}{c}{ Day $7^{2}$} & Day 8 & Day 9 & Day 10 \\
\hline -WCS -bST & $6.0 \pm 1.4$ & $1.3 \pm 0.4$ & $0.7 \pm 0.4$ & $0.6 \pm 0.1$ \\
+WCS +bST & $7.7 \pm 1.5$ & $2.1 \pm 0.4$ & $1.6 \pm 0.4$ & $0.5 \pm 0.1$ \\
+WCS -bST & $11.9 \pm 1.6$ & $2.4 \pm 0.5$ & $0.9 \pm 0.5$ & $0.6 \pm 0.1$ \\
+WCS +bST & $9.2 \pm 1.3$ & $2.0 \pm 0.4$ & $1.9 \pm 0.4$ & $0.7 \pm 0.1$ \\
\hline
\end{tabular}

${ }^{1}$ Treatment groups: -WCS -bST = no whole cottonseed diet, no bST injected; -WCS +bST = no whole cottonseed diet, but bST injected; +WCS -bST = whole cottonseed diet, no bST injected; +WCS +bST = whole cottonseed diet and bST injected.

${ }^{2}$ Progesterone concentrations in WCS diet group cows tended to differ from that of cows in no WCS diet groups $(P<0.10)$ on $d 7$. Concentrations of progesterone in plasma did not differ on $\mathrm{d} 8,9$, or 10.

$(P=0.06)$ to develop slightly larger CL $(33.9 \pm 0.4 \mathrm{~mm})$ than cows not fed WCS diet $(31.6 \pm 0.4 \mathrm{~mm})$.

In evaluating the dynamics of CL regression ( 7 to 10), the regression curve for $\mathrm{P}_{4}$ concentrations was influenced by the WCS diet $(P<0.05)$. However, cows in all diets completed CL regression by $d 10$. The difference in $\mathrm{P}_{4}$ curves can be attributed to the tendency for high concentrations of $\mathrm{P}_{4}(P<0.10$; Table 2$)$ on $\mathrm{d} 7$ in WCS diet groups.

\section{HDL Analysis}

HDL increased through the first 11 wk of lactation for all treatments $(P<0.01$; Table 3$)$. The WCS $\operatorname{diet}(P$ $<0.01)$ stimulated HDL. No interaction between WCS and bST was detected for HDL.

\section{DISCUSSION}

Ovarian follicular and luteal responses to a WCS diet and bST treatment in a controlled GnRH-induced follicular wave were examined in the present study. The number of Class 1 (2 to $5 \mathrm{~mm}$ ) and Class 3 ( $\geq 10 \mathrm{~mm}$ ) follicles did not differ $(P>0.05)$ among treatments due to WCS diet or bST. Associated with the induction of ovulation due to GnRH injection on d 0 , the number of Class 3 follicles declined and increased thereafter following recruitment of a new follicular wave. In contrast, the number of Class 2 (6 to $9 \mathrm{~mm}$ ) follicles was influenced differentially by bST, depending upon whether the diets contained WCS or not. For example, bST-treated cows receiving a WCS diet had a greater number of Class 2 follicles (Figure 2B), apparently due to the presence of a dominant follicle with reduced dominance. In contrast, sustained recruitment of Class 2 
Table 3. Least-squares means of plasma HDL (mg/dl) for cows fed WCS (+/-) and treated with bST (+/-).

\begin{tabular}{|c|c|c|c|c|c|c|c|}
\hline \multirow[b]{2}{*}{ Treatment2 } & \multicolumn{6}{|c|}{ Week } & \multirow{2}{*}{$\begin{array}{l}\text { Overall mean } \\
\text { pooled SEM }\end{array}$} \\
\hline & 1 & 2 & 6 & 7 & 10 & 11 & \\
\hline -WCS -bST & 48.2 & 59.5 & 64.9 & 77.1 & 75.8 & 79.8 & $67.5 \pm 5.2$ \\
\hline -WCS +bST & 59.0 & 64.3 & 73.2 & 76.3 & 81.0 & 86.7 & $73.5 \pm 4.2$ \\
\hline +WCS -bST & 69.3 & 74.3 & 91.3 & 99.6 & 101.2 & 104.1 & $89.9 \pm 4.7$ \\
\hline +WCS +bST & 61.8 & 70.0 & 98.8 & 103.7 & 97.1 & 105.0 & $89.4 \pm 4.3$ \\
\hline
\end{tabular}

\footnotetext{
${ }^{1}$ Treatment groups: $-\mathrm{WCS}-\mathrm{bST}=$ no whole cottonseed diet, no bST injected; $-\mathrm{WCS}+\mathrm{bST}=$ no whole cottonseed diet, but bST injected; +WCS -bST = whole cottonseed diet, no bST injected; +WCS +bST = whole cottonseed diet and bST injected. Main effect of WCS, $P<0.02$
}

follicles following GnRH injection was greatly reduced in bST-treated cows not fed WCS (Figure 2A) indicating that bST stimulated the growth of a follicle with greater dominance-one that reduced recruitment and/or enhanced turnover of Class 2 follicles when WCS was not present in the diet. Previously, Wehrman et al. (1991) observed that a WCS diet stimulated the number of medium-sized follicles. Somatotropin administration in lactating dairy cows increased the population of Class 2 follicles during the first follicular wave (Lucy et al., 1992) and raised the concentration of IGF-1 in plasma (Bilby et al., 1999; Newbold et al., 1997). The nutritional regulation of IGF-I and GH and their effects on follicular and luteal function has been reviewed recently (Lucy et al., 1999). Thus, diet- and bST-induced effects were the likely underlying causes for the alteration of follicular dynamics accompanying the use of bST in lactating cows, but this effect seems to be dependent upon increased dietary fat provided in the form of WCS.

Kirby et al. (1997a) reported that GH increased the size of the dominant follicle in the preovulatory period. In the present study, no such size increase was observed in the induced dominant follicle of bST-treated cows. Overall, bST treatment resulted in greater follicular dominance in the absence of a WCS diet, but not when a WCS diet was fed. The exact mechanism by which bST, interacting with diet, was able to modify the patterns of follicular dynamics in the ovary is not known. However in dairy cows, bST administration altered baseline LH secretion (Schemm et al., 1990; Waterman et al., 1993), and this could alter the normal function of the ovary. Studies have shown that bST treatment increased plasma IGF-1 concentration in lactating dairy cows (De la Sota et al., 1993; Newbold et al., 1997), and increased the number of follicles (6 to $15 \mathrm{~mm}$ ) in lactating dairy cows (De la Sota et al., 1993). Thus, bST may affect follicle development both directly and indirectly. In the present study, a differential bST effect occurred due to diet. An alternative description of the diet $\times$ bST interaction is that cows fed WCS in the absence of bST develop dominant follicles that exert greater dominance based on a decrease in recruitment of Class 2 follicles (Figure 2B). This induction of follicular dominance due to WCS diets could be induced in diets without WCS if bST was administered (Figure 2A). In contrast, bST treatment reduced follicular dominance induced by feeding WCS to cows.

There was no evidence that plasma $\mathrm{P}_{4}$ was altered by the low dose of bST. Administration of higher bST doses to cows influences ovarian function (Lucy et al., 1999), and increases plasma concentrations of IGF-I (Bilby et al., 1999) and progesterone (Schemm et al., 1990). Receptors for $\mathrm{GH}$ are present in abundance in the bovine CL, the primary location being the large luteal cell (Lucy et al., 1993a). Though plasma IGF-I concentrations were not determined in the present study, it is likely that the low doses of bST administered in this experiment increased IGF-I in blood similar to the findings of Bilby et al. (1999), who reported increased IGF-I in plasma after administration of $167 \mathrm{mg}$ of bST (Posilac). Nevertheless, plasma $\mathrm{P}_{4}$ appeared to be nonresponsive to bST and/or IGF-I in this study.

In cows having CL during the experimental period, WCS increased plasma concentrations of $\mathrm{P}_{4}$. This increase was evident after adjusting for number of CL during the experimental period. Grummer and Carroll (1991) postulated that HDL was the major lipoprotein fraction supplying cholesterol to luteal tissues for $\mathrm{P}_{4}$ synthesis. Adding HDL with a high cholesterol:protein ratio to luteal cell cultures in vitro increased $\mathrm{P}_{4}$ production. However, no difference was noted between control and fat-supplemented cows in their ability to stimulate $\mathrm{P}_{4}$ production (Carroll et al., 1992) when pregnant lactating cows were used. In another study, Hawkins et al. (1995) demonstrated that early-lactation cows fed a diet containing the calcium soaps of fatty acids had approximately twice the concentration of cholesterol, $\mathrm{HDL}$, and $\mathrm{P}_{4}$ in serum than cows on a control diet had. The present study also focused on early-lactation cows, and the clear elevation in HDL cholesterol in cows fed WCS diets likely accounted for the higher $\mathrm{P}_{4}$ in plasma of WCS-fed cows (Table 2). As reported by Hawkins et al. (1995), the increased concentration of $\mathrm{P}_{4}$ in the present study may be associated with increased lipid 
accumulation within the CL and a slower rate of $\mathrm{P}_{4}$ disappearance from peripheral circulation.

Supplementation of dietary fats increased serum concentrations of GH, insulin, and cholesterol (Thomas et al., 1997). The same workers observed that concentrations of cholesterol and IGF-I in follicular fluid also were increased following fat feeding. In the present study, the WCS diet (15\% of DM) provided approximately $671 \mathrm{~g}$ of fat intake per cow per day. Based on the estimated delivery of linoleic acid to the small intestine, which escapes biohydrogenation in the rumen, up to $168 \mathrm{~g}$ of linoleic acid may be absorbed (Staples et al., 1998). Thus, the increased availability of fat (including esterified cholesterol) associated with the WCS diets may have permitted an increase in CL progesterone secretion. Generally, feeding high-fat diets to cattle stimulates ovarian function (Hightshoe et al., 1991; Lucy et al., 1991b; Staples et al., 1998). During the postpartum period, the effects of fat supplementation have been attributed to the associated increase in energy intake and the change in energy balance (Butler and Smith, 1989), elevated blood cholesterol levels, and enhanced ovarian luteal activity (Hightshoe et al., 1991; Wehrman et al., 1991). Furthermore, studies show that fat, in the form of calcium soaps of long-chain fatty acids, and not increased energy intake, stimulated ovarian function (Sklan et al., 1991) and caused the development of larger preovulatory follicles (Lucy et al., 1991a; 1991b; 1993b). Diets enriched with longchain fatty acids are suggested to modulate the production of $\mathrm{P}_{4}$ through increased availability of cholesterol, reduced synthesis of $\mathrm{PGF}_{2 \alpha}$ in the uterus, and possible alteration in growth hormone and IGF-1 secretion (Grummer and Carroll, 1991; Mattos et al., 2000; Staples et al., 1998).

In dairy cows, the dosage and time of bST administration with respect to calving seem to have effects on reproductive responses. In the present study, an average of $14-\mathrm{mg} / \mathrm{d}$ of bST ( $208 \mathrm{mg} / 14 \mathrm{~d}$ ) was administered starting within $7 \mathrm{~d}$ after calving. Cows given $25 \mathrm{mg}$ of $\mathrm{bST} / \mathrm{d}$ beginning at 35 or $70 \mathrm{~d}$ postpartum and continuing until $200 \mathrm{~d}$ postpartum had increased concentrations of $\mathrm{P}_{4}$ and LH pulse frequency (Schemm et al., 1990). In contrast, dosing $40 \mathrm{mg} / \mathrm{d}$ of bST starting 32 or $85 \mathrm{~d}$ postpartum and continuing for up to $180 \mathrm{~d}$ resulted in lower plasma $\mathrm{P}_{4}$ and basal concentrations of LH (Waterman et al., 1993). This likely indicates a negative effect of bST on ovarian function at higher doses and perhaps reduced reproductive performance (Cole et al., 1992). The benefit of using lower doses for improved reproductive performance has been described elsewhere (Stanisiewski et al., 1992).

Current results demonstrate that bST interacts with diets containing different levels of fat to alter ovarian follicular activity. Additional studies are warranted to understand interactions between nutrition and reproduction in cows treated with bST in order to optimize reproductive management and fertility.

\section{ACKNOWLEDGMENTS}

This study received financial support from the NRI Competitive Grant Program/USDA, grant no. 9835203-6367. This is Florida Agricultural Experimental Station Journal Series No. R-08933.

\section{REFERENCES}

Adams, A. L. 1998. Dietary effects of rumen fermentation, milk production, and reproduction of dairy cattle, and economic implications for dairy production. Ph.D. Dissertation. University of Florida, Gainesville.

Bauman, D. E. 1992. Bovine somatotropin: Review of an emerging technology. J. Dairy Sci. 75:3432-3451.

Bauman, D. E., and W. B. Currie. 1980. Partitioning of nutrients during pregnancy and lactation: A review of mechanisms involving homeostasis and homeorrhesis. J. Dairy Sci. 63:1514-1529.

Bilby, C. R., J. F. Bader, B. E. Salfen, R. S. Youngquist, C. N. Murphy, H. A. Gaverick, B. A. Crooker, and M. C. Lucy. 1999. Plasma GH, IGF-I, and conception rate in cattle treated with low doses of recombinant bovine GH. Theriogenology 51:1285-1296.

Burke, J. M., R. L. De la Sota, C. A. Risco, C. R. Staples, E. J.-P. Schmitt, and W. W. Thatcher. 1996. Evaluation of timed insemination using a gonadotropin-releasing hormone agonist in lactating dairy cows. J. Dairy Sci. 79:1385-1393.

Butler, W. R., and R. D. Smith. 1989. Interrelationships between energy balance and postpartum reproductive function in dairy cattle. J. Dairy Sci. 72:767-783.

Carroll, D. J., R. R. Grummer, and M. K. Clayton. 1992. Stimulation of luteal cell progesterone production by lipoproteins from cows fed control or fat-supplemented diets. J. Dairy Sci. 75:2205-2214.

Cole, W. J., P. J. Eppard, B. G. Boysen, K. S. Madsen, R. H. Sorbet, M. A. Miller, R. L. Hintz, T. C. While, W. E. Ribelin, B. G. Hammond, R. T. Collier, and G. M. Lanza. 1992. Response of dairy cows to high doses of a sustained-release bovine somatotropin administered during two lactations. 2. Health and reproduction. J. Dairy Sci. 75:111-123.

Cole, W. J., K. S. Madsen, R. L. Hintz, and R. T. Collier. 1991. Effect of recombinant-derived bovine somatotropin on reproductive performance of dairy. Theriogenology. 36:573-595.

De la Sota, R. L., M. C. Lucy, C. R. Staples, and W. W. Thatcher. 1993. Effects of recombinant bovine somatotropin (Sometribove) on ovarian function in lactating and nonlactating dairy cows. J. Dairy Sci. 76:1002-1013.

Grummer, R. R., and D. J. Carroll. 1991. Effects of dietary fat on metabolic disorders and reproductive performance of dairy cattle. J. Anim. Sci. 69:3838-3852.

Hawkins, D. E., K. D. Niswender, G. M. Oss, C. L. Moeller, K. G. Odde, H. R. Sawyer, and G. D. Niswender. 1995. An increase in serum lipids increases luteal lipid content and alters the disappearance rate of progesterone in cows. J. Anim. Sci. 73:541-545.

Hightshoe, R. B., R. C. Cochran, L. R. Corah, G. H. Kiracofe, D. L. Harmon, and R. C. Perry. 1991. Effects of calcium soaps of fatty acids on postpartum reproductive function in beef cows. J. Anim. Sci. 69:4097-4103.

Kirby, C. R., M. F. Smith, D. H. Keisler, and M. C. Lucy. 1997a. Follicular function in lactating dairy cows treated with sustainedrelease bovine somatotropin. J. Dairy Sci. 80:273-285.

Kirby, C. R., S. J. Wilson, and M. C. Lucy. 1997b. Response of dairy cows treated with bovine somatotropin to a luteolytic dose of prostaglandin $\mathrm{F}_{2}$. J. Dairy Sci. 80:286-294. 
Knickerbocker, J. J., W. W. Thatcher, F. W. Bazer, M. Drost, D. H. Barron, K. B. Fincher, and R. M. Roberts. 1986. Proteins secreted by day-16 to -18 conceptuses extend corpus luteum function in cows. J. Reprod. Fertil. 77:381-391.

Littell, R. C., G. A. Milliken, W. W. Stroup, and R. D. Wolfinger. 1996. SAS for Mixed Models. SAS Institute Inc., Cary, NC.

Lucy, M. C., J. Beck, C. R. Staples, H. H. Head, R. L. De la Sota, and W. W. Thatcher. 1992. Follicular dynamics, plasma metabolites, hormones and insulin-like growth factor-I (IGF-I) in lactating cows with positive or negative energy balance during preovulatory period. Reprod. Nutr. Dev. 32:331-341.

Lucy, M. C., C. R. Bilby, C. J. Kirby, W. Yuan, and C. K. Boyd. 1999. Role of growth hormone in development and maintenance of follicles and copora lutea. J. Reprod. Fertil. Suppl. 54:49-59.

Lucy, M. C., R. J. Collier, M. L. Kitchell, J. J. Dibner, S. D. Hauser, and G. G. Krivi. 1993a. Immunohistochemical and nucleic acid analysis of somatotropin receptor populations in the bovine ovary. Biol. Reprod. 48:1219-1227.

Lucy, M. C., R. L. De la Sota, C. R. Staples, and W. W. Thatcher. 1993b. Ovarian follicular population in lactating dairy cows with recombinant bovine somatotropin (Sometribove) or saline and fed diets differing in fat content and energy. J. Dairy Sci. 76:10141027.

Lucy, M. C., C. R. Staples, F. M. Michel, and W. W. Thatcher. 1991a. Energy balance and size and number of ovarian follicles detected by ultrasonography in early postpartum dairy cows. J. Dairy Sci. $74: 473-482$.

Lucy, M. C., C. R. Staples, F. M. Michel, W. W. Thatcher, and D. J. Bolt. 1991b. Effect of feeding calcium soaps to early postpartum dairy cows on plasma prostaglandin $\mathrm{F}_{2 \alpha}$, luteinizing hormone, and follicular growth. J. Dairy Sci. 74:483-489.

Mattos, R., C. R. Staples, and W. W. Thatcher. 2000. Effects of dietary fatty acids on reproduction in ruminants. Rev. Reprod. 5:38-45.

National Research Council. 1988. Nutrient requirements of dairy cattle. 6th revised ed. National Academy of Sciences, Washington, D.C.

Newbold, J. A., R. B. Heap, C. G. Prosser, R. H. Phipps, F. Adriaens, and D. L. Hard. 1997. The effects of bovine somatotropin and diet on somatotropin binding sites in hepatic tissue of lactating dairy cows. J. Dairy Sci. 80:1085-1091.

Pursley, J. R., M. O. Mee, and M. C. Wiltbank. 1995. Synchronization of ovulation in dairy cows using $\mathrm{PGF}_{2 \alpha}$ and $\mathrm{GnRH}$. Theriogenology 44:915-923.

Schemm, S. R., D. R. Deaver, L. C. Griel, and L. D. Muller. 1990. Effects of recombinant bovine somatotropin on luteinizing hormone and ovarian function in lactating dairy cows. Biol. Reprod. 42:815-821.

Sklan, D., U. Moalles, and Y. Folman. 1991. Effects of feeding calcium soaps of fatty acids on production and reproductive responses in high producing lactating cows. J. Dairy Sci. 74:510-517.

Stanisiewski, E. P., L. F. Krabill, and J. W. Lauderdale. 1992. Milk yield, health, and reproduction of dairy cows given somatotropin (Somavubove) beginning early postpartum. J. Dairy Sci. 75: 2149-2164.

Staples, C. R., J. M. Burke, and W. W. Thatcher. 1998. Influence of supplemental fats on reproductive tissues and performance of lactating cows. J. Dairy Sci. 81:856-871.

Staples, C. R., W. W. Thatcher, and J. H. Clark. 1990. Relationship between ovarian activity and energy status during the early postpartum period of high producing dairy cows. J. Dairy Sci. 73:938-947.

Thomas, M. G., B. Bao, and G. L. Williams. 1997. Dietary fats varying in their fatty acid composition differentially influence follicular growth in cows fed isoenergetic diets. J. Anim. Sci. 75:2512-2519.

Waterman, D. F., W. J. Silvia, R. W. Hemken, G. Heersche, Jr., T. S. Swenson, and R. G. Eggert. 1993. Effect of bovine somatotropin on reproductive function in lactating dairy cows. Theriogenology. 40:1015-1028.

Wehrman, M. E., T. H. Welsh, and G. L. Williams. 1991. Diet-induced hyperlipidemia in cattle modifies the intrafollicular cholesterol environment, modulates ovarian follicular dynamics, and hastens the onset of postpartum luteal activity. Biol. Reprod. 45:514-522.

Wilcox, C. J., W. W. Thatcher, and F. G. Martin. 1990. Statistical analysis of repeated measurements in physiology experiments. Pages 141-155 in Proc. Final Res. Coord. Meet. International Atomic Energy Agency, Vienna, Austria.

Williams, G. L. 1989. Modulation of luteal activity in postpartum beef cows through changes in dietary lipid. J. Anim. Sci. 67:785-793. 